\title{
Thermal Stability and Decomposition Study of Epoxy/Clay Nanocomposites
}

\author{
(Kestabilan Terma dan Kajian Penguraian Epoksi/Lempung Terubah Nano)
}

\author{
S. DZUHRI, N.Y. YUHANA* \& M. KHAIRULAZFAR
}

\section{ABSTRACT}

This study utilized the incorporation of nanoparticle filler into an epoxy system to study the effect of different nanosized montmorillonite (MMT) fillers on the thermal stability and mechanical properties of epoxy. The sample was prepared using diglycidyl ether of bisphenol A (DGEBA) with different surface treatments of montmorillonite filler by mechanical stirring. The results of thermal stability and mechanical properties of epoxy/clay system obtained from thermal gravimetric analyzer (TGA), universal testing machine (UTM) and scanning electron microscopy (SEM) were discussed. With the same amount of filler introduced into the system, different thermal stability of epoxy composite can be observed. Bentonite, which contained other contaminant components, can downgrade the enhanced properties of the filler.

Keywords: Cloisite; epoxy; montmorillonite; nanocomposite; thermal stability

ABSTRAK

Kajian ini dijalankan bagi mengaplikasikan pengisi bersaiz nano ke dalam sistem epoksi yang memberi kesan terhadap kestabilan terma dan ciri-ciri mekanikalnya. Sampel yang digunakan adalah daripada epoksi diglicidil eter bisfenol A (DGEBA) dengan pengisi montmorilonit yang berbeza olahan permukaan melalui kaedah pengadukan mekanikal. Hasil kestabilan terma dan ciri-ciri mekanikal sistem epoksi/lempung diperoleh daripada alat analisis gravimetri terma (TGA), mesin ujian universal dan mikroskopi elektron imbasan (SEM) dibincangkan dengan teliti. Dengan jumlah pengisi yang sama, hasil kestabilan terma yang berbeza dapat diperoleh. Bentonit yang mengandungi bendasing dapat menurunkan ciri-ciri penambah kekuatan pengisi tersebut.

Kata kunci: Epoksi; kestabilan terma; kloisit; montmorilonit; terubah nano

\section{INTRODUCTION}

The incorporation of nanometer-sized fillers in polymer matrices to improve thermal, mechanical, barrier, electrical and optical properties has gained interest recently. The most common types of polymer nanocomposites incorporate silicate, carbon or metal oxide nanoparticles. In polymer nanocomposites, a small amount of silicate nanoparticles (less than $5 \mathrm{wt}$. \%) is commonly used. The types of silicate used include natural silicate (montmorillonite and hectorite) and synthetic silicate (laponite, magadiite and flourohectorite). However, the most commonly used and studied nanoclay is montmorillonite (MMT), a layered aluminosilicate. An interesting feature of the layered silicates is their high aspect ratio. MMT is also available in the market as organically modified clay. This facilitates the dispersion of the layers in a polymer matrix at nanometer scale.

The arrangement of silicate particles in a polymer matrix can be found as microsized agglomerates, as in the case of common fillers, or as intercalated or exfoliated particles (Aijuan \& Liang 2002; Becker \& Simon 2005; Carrasco \& Pagès 2008). Normally, the three structures could be observed in a single polymer/ silicate nanocomposite. Hence, in order to study the polymer nanocomposite morphology, both microstructure and nanostructure must be observed and considered. The most common techniques used are wide angle X-ray diffraction (WAXD), transmission electron microscope (TEM) and scanning electron microscopy (SEM). SEM could also be used to explain the fracture toughness behavior of nanocomposite.

Epoxy/layered silicate nanocomposites exhibit improved thermal, barrier and mechanical properties (Carrasco \& Pagès 2008). Table 1 summarizes the research on thermal stability and kinetics of decomposition of epoxy/ clay nanocomposites reported by several researchers.

Based on the Geological Survey Department of Malaysia, there is a bentonite resource in Sabah, Malaysia (Irawan \& Samsuri 2007). Bentonite has been commercially used as a flame retardant in plastic material by further purification of the filler content (Cárdenas et al. 2009). Due to the use of bentonite in plastic polymer area, many researchers studied these bentonite properties and tried to maximize the enhancing effect in plastic polymer (Erdemoğlu et al. 2004; Hussin et al. 2011; Ruiz-Hitzky et al. 2011; Sayllkan et al. 2004). Since there is no research regarding nanometer-sized bentonite from Sabah has been reported, hence, the authors has decided to explore its potential as plastic filler in terms of thermal exposure and its morphologies in epoxy. The current research 
TABLE 1. Current research of epoxy/clay nanocomposites

\begin{tabular}{ll}
\hline Systems & Observations \\
\hline Epoxy/Cloisite 30B & E $_{\mathrm{a}}$ values are higher for binary system compared to neat epoxy (Yuhana et al. 2012) \\
The amount of filler (wt \%) influenced the $\mathrm{E}_{\mathrm{a}}$ value of the system (Aijuan \& Liang 2002; Zhou \\
et al. 2007) \\
The incorporation of nanofiller into 3,5-diamino- $N$-(4-(quinolin-8-yloxy) phenyl) benzamide \\
(DQPB) resulted in the maintained onset temperature of the system but increased the thermal \\
stability of the system (Isik-Gulsac et al. 2003) \\
Increased of natural $\left(\mathrm{Na}^{+}\right)$filler content increased the mass loss of the system (Tcherbi-Narteh et \\
al. 2013)
\end{tabular}

reported results on the effects of commercially available montmorillonite and Sabah bentonite (i.e. montmorillonite) in epoxy on the thermal properties of the binary system. In this paper, the thermal decomposition and morphology study of room temperature cured samples have been reported.

\section{EXPERIMENTAL DETAILS}

\section{MATERIALS}

Bisphenol A diglycidyl ether (187 epoxy equivalent weight, Epikote 828 obtained from Hexion Specialty Chemical Korea) was used as the polymer matrix. Epikure D230, commonly known as Polyetheramine D230 (PEA), which contain alpha-(2-aminomethylethyl)-omega-(2aminomethylethoxy)-poly(oxy(methyl-1,2-ethanedyl)) with their amine number, amine value, and water content of $461.7 \mathrm{mg} \mathrm{KOH} / \mathrm{g}, 8.23 \mathrm{meq} / \mathrm{g}$ and $0.02 \mathrm{wt} \%$, respectively, was used as a curing agent in the system. Different montmorillonite surface-modified layered silicate clay were used as the filler for the system. These include natural montmorillonite (Cloisite $\mathrm{Na}$ ), montmorillonite with organically-modified surface (Cloisite 30B) using ammonium bis(hydroxyl ethyl) methyl tallow alkyl salt supplied by Southern Clay Products, USA, as well as a pure solid filler known as Sabah bentonite that contained some amount of montmorillonite, quartz, kaolinite and illite.

\section{SAMPLE PREPARATION BY MECHANICAL STIRRING}

Epoxy resin was preheated at $60^{\circ} \mathrm{C}$ to lower the viscosity so that it was easier for the added clay to disperse and this step was conducted using HTS 1003 heating plate with heating rate of $2^{\circ} \mathrm{C} / \mathrm{min}$ to ensure that the exothermic peak was not achieved. $2 \mathrm{wt} \%$ filler was added into 100 parts of epoxy resin based on the thesis reported by Dat (2013) and mixed by mechanical stirring using LH (VELP Scientifica) stirrer with 3 blades at the speed of $50 \mathrm{rpm}$ for $1 \mathrm{~h}$. This speed assisted the clay to break into small particles and helped to increase the clay/epoxy interfaces. The mixture was then added with $32.8 \mathrm{~g}$ of PEA curing agent with continuous stirring for $10 \mathrm{~min}$. The obtained pre-polymer was then poured into a stainless steel mold with the dimensions of $100 \times 100 \times 5 \mathrm{~mm}$ and then cured at room temperature for 1 week. Later, the samples were characterized using several techniques. Different types of filler used in this study are shown in Table 2.

TABLE 2 . Weight $\%$ of fillers to 100 parts of resin

\begin{tabular}{lccc}
\hline \multirow{2}{*}{ Type } & \multicolumn{3}{c}{ Component weight (gram) } \\
\cline { 2 - 4 } & $\begin{array}{c}\text { Cloisite } \\
\mathrm{Na}^{+}\end{array}$ & $\begin{array}{c}\text { Cloisite } \\
30 \mathrm{~B}\end{array}$ & $\begin{array}{c}\text { Sabah } \\
\text { Bentonite }\end{array}$ \\
\hline DGEBA/PEA & 0 & 0 & 0 \\
DGEBA/Na $/$ PEA & 2 & 0 & 0 \\
DGEBA/30B/PEA & 0 & 2 & 0 \\
DGEBA/Sabah/PEA & 0 & 0 & 2 \\
\hline
\end{tabular}

\section{CHARACTERIZATION}

Thermalgravimetric Analysis (TGA) Characterization of TGA of the samples used a Netzsch model STA 449 and conducted at different rates of $10,15,20$ and $30^{\circ} \mathrm{C} / \mathrm{min}$ (Table 3 ). Some of the parameters examined include onset temperature $\mathrm{T}_{\text {onset }}$, temperature at the maximum rate of mass loss $\mathrm{T}_{\max }$ and residual mass percentage. Then, the kinetic rate for the decomposition of the sample was obtained from the plotted graph using the given formula by Flynn-WallOzawa (Gu \& Liang 2003):

$$
\ln q=-1.052 \frac{E_{a}}{R T_{\max }}+C,
$$

where $\mathrm{q}$ is the heating rate $\left({ }^{\circ} \mathrm{C} / \mathrm{min}\right)$; $\mathrm{C}$ is the Doyle's approximation constant; $\mathrm{R}$ is the gas constant $(0.008324$ $\mathrm{kJ} / \mathrm{mol} \mathrm{K})$; $\mathrm{E}_{\mathrm{a}}$ is the activation energy $(\mathrm{kJ} / \mathrm{mol})$; and $\mathrm{T}_{\max }$ is the temperature at the maximum rate of mass loss $\left({ }^{\circ} \mathrm{C}\right)$.

Kissinger equation was also used for comparison purpose, which is given by the equation:

$$
\ln \frac{H_{r}}{T^{2}}=-\left(\frac{E_{a}}{R}\right)\left(\frac{1}{T}\right)-\ln \left[\frac{A R n(1-\alpha)^{n-1}}{E_{a}}\right],
$$

where, $\alpha$ is the decompose ratio; $\mathrm{n}$ is the reaction order; $\mathrm{E}$ is the activation energy $(\mathrm{J} / \mathrm{mol}) ; \mathrm{H}_{\mathrm{r}}$ is the heating rate $\left({ }^{\circ} \mathrm{C} /\right.$ $\mathrm{min})$; $\mathrm{T}$ is the temperature at the maximum rate of mass loss $(\mathrm{K})$; and $\mathrm{R}$ is the gas constant $(0.008314 \mathrm{~kJ} / \mathrm{mol} \mathrm{K})$. 
From these two equations, the graphs of $\ln \mathrm{q} v \mathrm{vs} 1 / \mathrm{T}_{\max }$ from Flynn-Wall-Ozawa and $\ln \left(H_{r} / T^{2}\right)$ vs $1 / T$ from the Kissinger equation were plotted and analyzed (Chiang et al. 2006).

Scanning Electron Microscopy (SEM) and Energy Disperse X-Ray Analysis (EDX) SEM analysis was carried out when the sample was totally cured after 1 week using a SEM machine model LEO 1550. The sample was break into a small part and the surface was then coated with gold from 90 to $100 \AA$ A before it was sent to the SEM machine to increase the conductivity of electron through the surface of the sample surface. SEM analysis provides an activation voltage that change from 2 to $5 \mathrm{kV}$. Energy disperse X-ray analysis was also carried out using the same machine as SEM analysis. The main focus of EDX analysis is to determine the amount of atomic number that is possible in the system.
FTIR The FTIR spectra of the organoclays dispersed in the system were recorded with a Nicolet model 6700 spectrophotometer with a scanning range from 4000 to $400 \mathrm{~cm}^{-1}$. The spectra were collected at a resolution of $4 \mathrm{~cm}^{-1}$ with over 64 scans. The mixed resin was placed into an optical glass cell according to the attenuated total reflectance (ATR) method.

\section{RESULTS AND DISCUSSION}

\section{THERMALGRAVIMETRIC ANALYSIS}

Figure 1 shows the TGA curves of the systems used. All the systems studied had undergone a single stage thermal degradation that occurred around $200^{\circ} \mathrm{C}$ due to elimination of water from the systems. For the temperature around $365^{\circ} \mathrm{C}$ and above, the decomposition of the polymer matrix occurred, which degraded the chemical bonds of the epoxy

TABLE 3. Analyzed data from TGA

\begin{tabular}{|c|c|c|c|c|}
\hline System & $\begin{array}{l}\text { Heating rate } \\
\left({ }^{\circ} \mathrm{C} / \mathrm{min}\right)\end{array}$ & $\mathrm{T}_{\text {onset }} \pm 0.1^{\circ} \mathrm{C}$ & $\mathrm{T}_{\max } \pm 0.1^{\circ} \mathrm{C}$ & $\begin{array}{c}\text { Residue } \\
(\%)\end{array}$ \\
\hline \multirow{4}{*}{ DGEBA/PEA } & 10 & 356.4 & 367.8 & 10.62 \\
\hline & 15 & 362.7 & 374.0 & 8.20 \\
\hline & 20 & 366.7 & 377.8 & 7.91 \\
\hline & 30 & 369.9 & 382.2 & 9.48 \\
\hline \multirow{4}{*}{ DGEBA/30B/PEA } & 10 & 355.9 & 372.8 & 8.88 \\
\hline & 15 & 364.5 & 376.8 & 5.16 \\
\hline & 20 & 367.4 & 379.5 & 6.74 \\
\hline & 30 & 374.7 & 386.5 & 9.38 \\
\hline \multirow{4}{*}{ DGEBA $/ \mathrm{Na}^{+} /$PEA } & 10 & 357.1 & 374.2 & 4.97 \\
\hline & 15 & 364.2 & 375.6 & 12.44 \\
\hline & 20 & 367.6 & 379.8 & 7.78 \\
\hline & 30 & 371.1 & 383.4 & 8.79 \\
\hline \multirow{4}{*}{ DGEBA/Sabah/PEA } & 10 & 344.6 & 362.7 & 9.62 \\
\hline & 15 & 354.2 & 368.6 & 8.41 \\
\hline & 20 & 358.3 & 374.5 & 8.86 \\
\hline & 30 & 365.4 & 379.1 & 9.24 \\
\hline
\end{tabular}

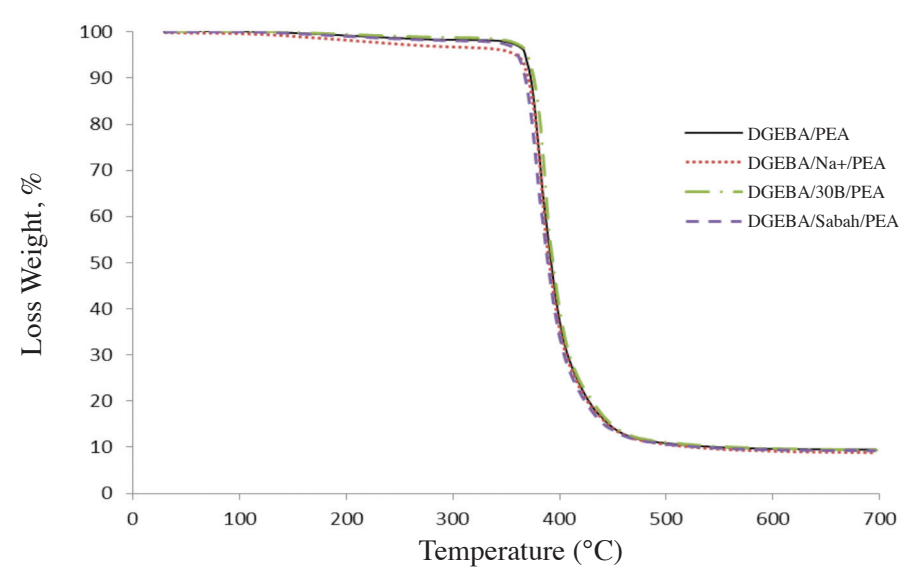

FIGURE 1. TGA curve of the systems 
network until the maximum loss was achieved. As shown in Figure 1, the decomposition started to slow down at the temperature around $450^{\circ} \mathrm{C}$ due to the blockage of the polymer gallery, which prevented the decomposed material from moving out of the gallery. The relative stability of DGEBA/MMT nanocomposite system was compared according to their initial decomposition temperature as shown in Table 2. DGEBA/PEA was used as the reference. It is already established that the incorporation of filler will increase the thermal stability of the system (IsikGulsac et al. 2003). From the result obtained, DGEBA/PEA without filler decomposed polymer matrix at $369.9 \pm 0.1^{\circ} \mathrm{C}$ at heating rate of $30^{\circ} \mathrm{C} / \mathrm{min}$. Meanwhile, DGEBA $/ 30 \mathrm{~B} / \mathrm{PEA}$ decomposed at $374^{\circ} \mathrm{C}$, DGEBA $/ \mathrm{Na}^{+} / \mathrm{PEA}$ at $371.9 \pm 0.1^{\circ} \mathrm{C}$ and DGEBA/Sabah/PEA at $365.4 \pm 0.1^{\circ} \mathrm{C}$ for heating rate of $30^{\circ} \mathrm{C} / \mathrm{min}$. This showed that the incorporation of Sabah bentonite lowered the decomposition temperature of the system due to the presence of other contaminants in the filler. This reason could be proven by the EDX analysis that showed the contents of Sabah bentonite.

The presence of $\mathrm{SiO}_{2}, \mathrm{Al}_{2} \mathrm{O}_{3}$ and $\mathrm{MgO}$ in nanocomposite could enhance thermal stability. Although Sabah bentonite contained material that enhanced thermal stability, however other factors may reduce the decomposition temperature of DGEBA/Sabah/PEA, such as the polymer chain of other components present in Sabah bentonite. Figure 2 shows the derivative (DTGA) graph of the DGEBA/MMT system obtained from TGA. The peak showed in this graph indicated the occurrence of the maximum rate mass loss during the decomposition. In ensuring the stability of the material used, the temperature at this maximum mass loss was required. Once again, the systems that contained Cloisite 30B filler had a higher temperature of the maximum rate of mass loss at $386.5^{\circ} \mathrm{C}$. The incorporation of chemical organophilic modification on the surface of montmorillonite increased the stability of the composite.

\section{ACTIVATION ENERGY OF EPOXY/CLAY SYSTEM}

By using Flynn-Wall-Ozawa method that has been modified by Doyle and Kissinger's method to calculate the kinetic energy of the decomposition process, the graph as shown in Figures 3 and 4 were obtained. The gradient represents the activation energy, $\mathrm{E}_{\mathrm{a}}$. For system with no filler, the activation energy, $\mathrm{E}_{\mathrm{a}}$, was $251.05 \mathrm{~kJ} /$ mol. Meanwhile, the Ea of $267.69 \mathrm{~kJ} / \mathrm{mol}$ and $363.11 \mathrm{~kJ} /$ mol were obtained for DGEBA/30B/PEA and DGEBA/ $\mathrm{Na}^{+} /$ PEA respectively. In terms of activation energy, Sabah bentonite filler showed the lowest value among other systems $(212.03 \mathrm{~kJ} / \mathrm{mol})$.

The lowest value obtained for DGEBA/Sabah/PEA was caused by the polymer structure in the matrix, which was the presence of other silicate components such as illite and quartz that produced undesired structure of the system (exfoliated or intercalated). Besides, there were some other factors that affected the activation energy of the system, which was polymer chain. It is known that longer polymer chain is less stable than shorter polymer chain as the energy required to break the bond is lower in long polymer chain than shorter chain. As seen in the EDX analysis, the presence of other contents in Sabah bentonite resulted in a lower crosslink density of the polymer. Therefore, it led to longer polymer chain for the system compared with others due to the space of crosslink area in the composite. This result is similar with those reported by Arridge and Speake (1972) and Grillet et al. (1991) in their study of curing and crosslink behavior of epoxy, which showed different crosslink densities when there were unwanted components and contaminants in

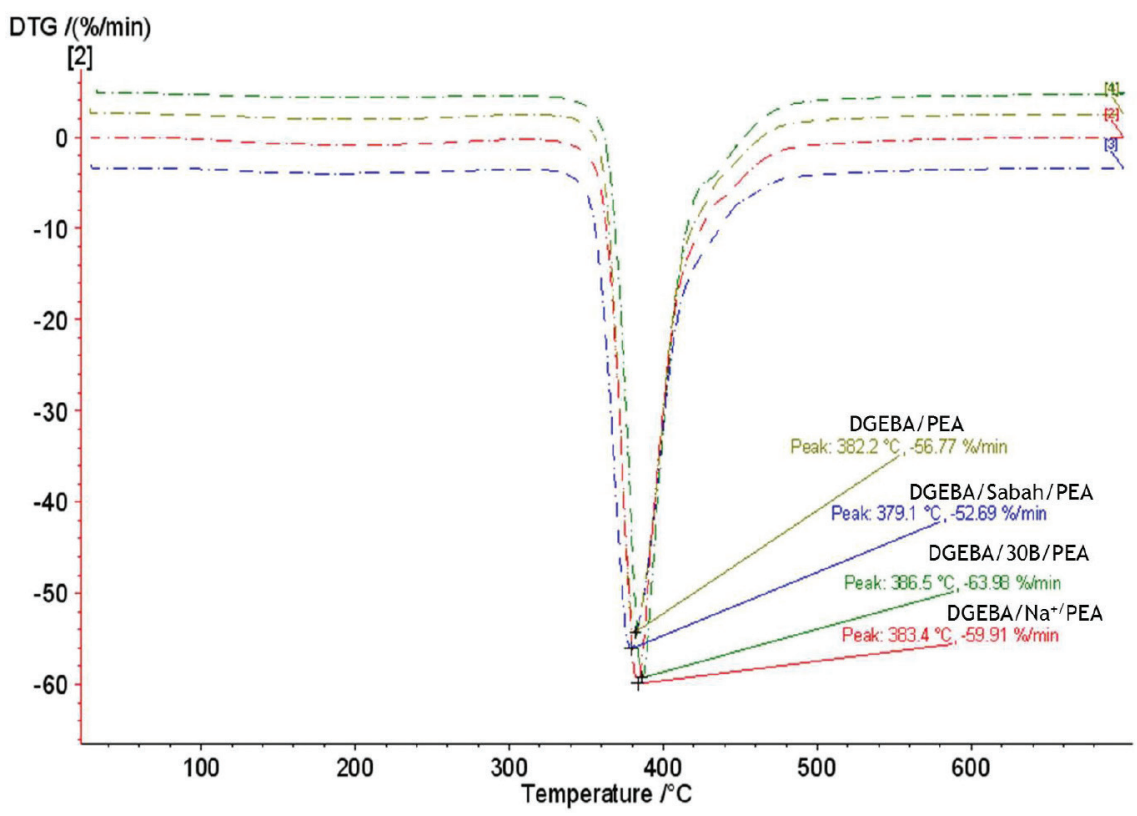

FIGURE 2. DTG curves for DGEBA/MMT system 


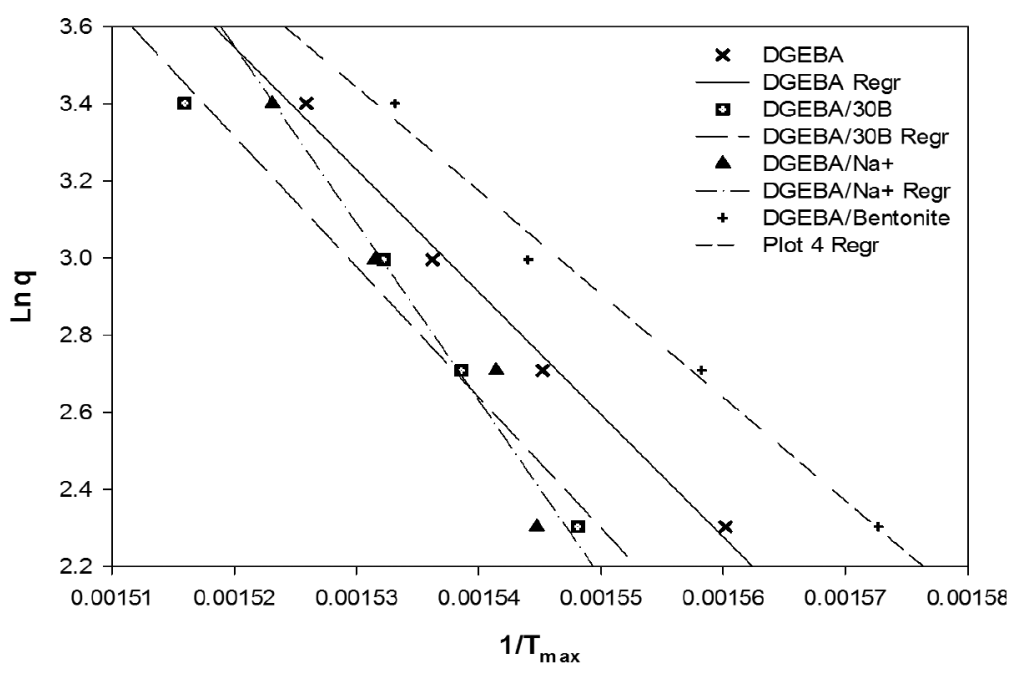

FIGURE 3. Flynn-Wall-Ozawa plot

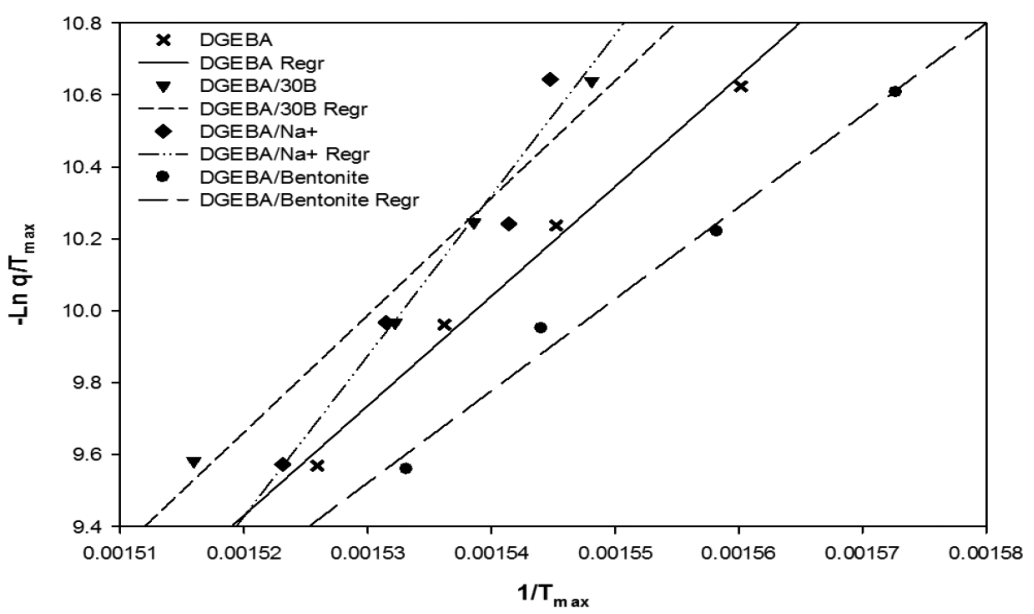

FIGURE 4. Kissinger plot

the matrix. In DGEBA/30B/PEA, the surface treatment with ammonium salt produced more organophilic Cloisite 30B, which eased the binding of DGEBA resin and nanofiller surface it, hence making it a longer chain. The summary of activation energy required by the system to decompose is presented by the bar chart in Figure 5 .

\section{SCANNING ELECTRON MICROSCOPY (SEM) AND ENERGY DISPERSE X-RAY ANALYSIS (EDX)}

Every sample should be coated with gold to increase the electron conductivity through the surface of the sample. Figure 6 shows the SEM result for each sample. As can be seen in Figure 6(a), DGEBA/PEA with no filler showed clear and smooth crack propagation for $100 \times$ magnification (Scale $20 \mu \mathrm{m}$ ). Figure 6(b), 6(c) and 6(d) shows the aggregation of nanofiller for DGEBA/30B/ PEA, DGEBA/Na ${ }^{+} /$PEA and DGEBA/Sabah/PEA samples, respectively. The aggregated structure of the filler on the sample was obviously seen. This result influenced the thermal stability of epoxy. From Figure 6(b) with 500x magnification (scale of $10 \mu \mathrm{m}$ ), aggregated particles were randomly arranged in every space, forming exfoliated or intercalated structure. The same result was obtained for DGEBA $/ \mathrm{Na}^{+} / \mathrm{PEA}$ sample, which clearly showed the aggregated particles with 5000× magnification (scale of $1 \mu \mathrm{m})$. Meanwhile, DGEBA/Sabah/PEA sample at 10000x magnification (scale of $200 \mathrm{~nm}$ ) showed the exfoliated filler in the structure. All the results can be probably proven by TEM analysis (not shown) to ensure their exfoliated or intercalated form.

The component in the system can be determined using EDX analysis. The amount of atomic number and mass percentage are summarized in Table 4 for each filler type. As expected from the EDX analysis, Sabah bentonite contained other components such as calcium, magnesium, ferum, zinc and bromine. Carbon and oxygen atoms obtained were from the epoxy, whereas silicon and aluminium atoms obtained were from the montmorillonite 


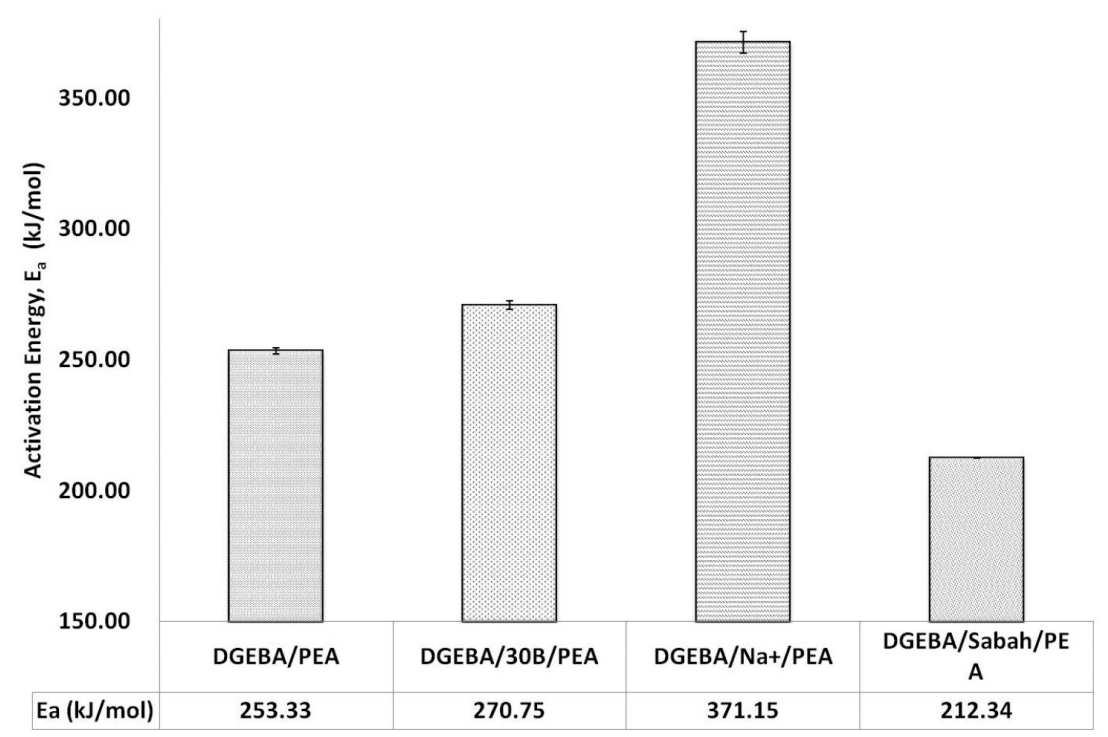

FIGURE 5. Activation energy of different nanofiller contents

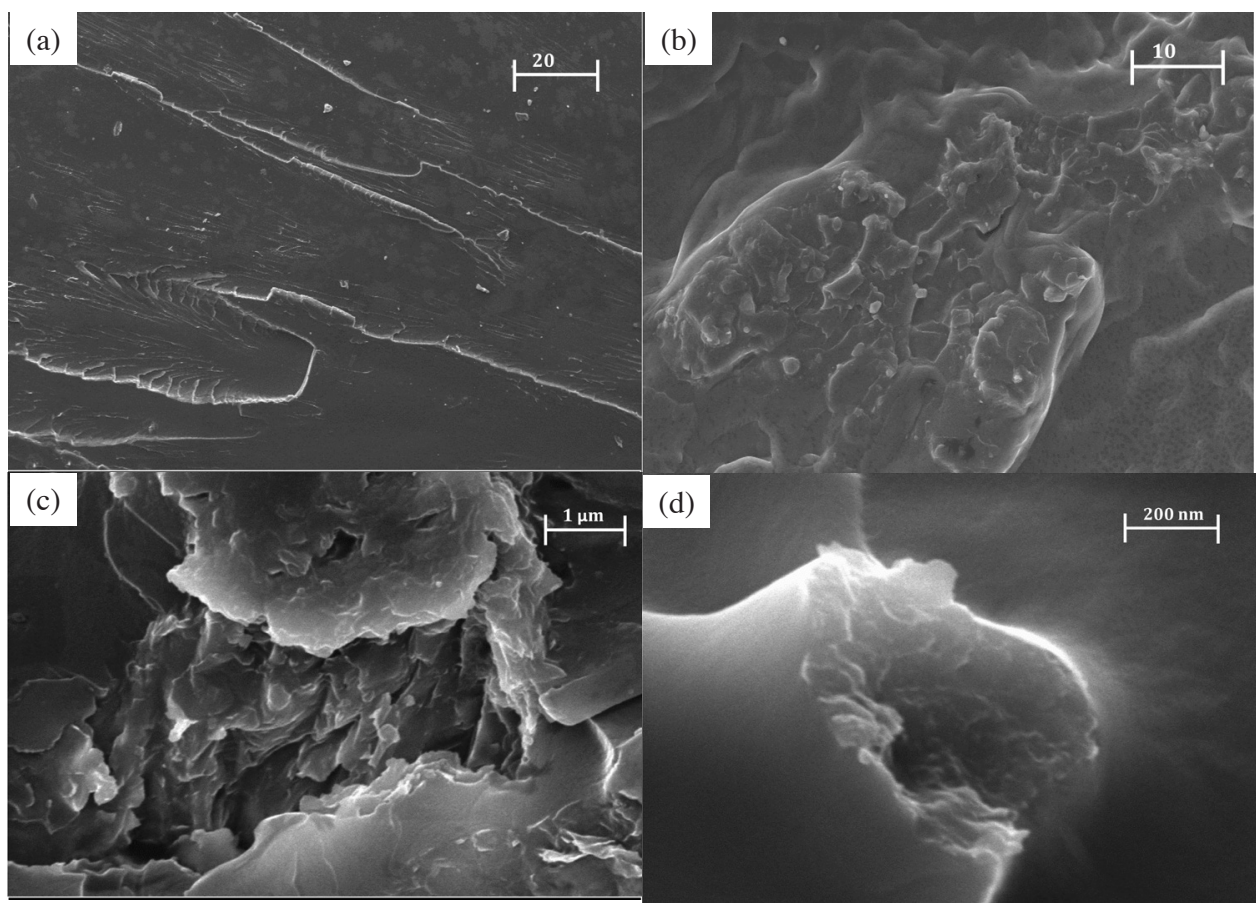

FIGURE 6. SEM analysis for a) DGEBA/PEA, b) DGEBA/30B/PEA, c) DGEBA/Na ${ }^{+} / \mathrm{PEA}$ and d) DGEBA/Sabah/PEA

filler. Some of the $\mathrm{Na}^{+}$in the DGEBA/Na $/ \mathrm{PEA}$ originated from the natural montmorillonite did not go through surface modification. The increase of thermal stability of DGEBA/MMT system due to the presence of aluminium and silicon was proven by the EDX result.

\section{FTIR}

There were differences for FTIR spectra of DGEBA/MMT for samples containing Cloisite $\mathrm{Na}^{+}$and Cloisite 30 fillers at different range of wavelength numbers from 4000 to 3600 $\mathrm{cm}^{-1}, 3000$ to $2800 \mathrm{~cm}^{-1}, 2400$ to $2300 \mathrm{~cm}^{-1}$ and in the range of 1800 to $1700 \mathrm{~cm}^{-1}$ for DGEBA/Sabah/PEA. The increase of peak at $2873 \mathrm{~cm}^{-1}$ band was due to the bending of $\mathrm{OH}$ bond in carboxylic acid group. Meanwhile, the bands at 1500 and $1601 \mathrm{~cm}^{-1}$ represented the asymmetric stretching of benzene ring. Since the sample contained montmorillonite, the increase of peak at $2357 \mathrm{~cm}^{-1}$ band could be related to the presence of $\mathrm{P}-\mathrm{H}$ bond that was represented by the band at $2400 \mathrm{~cm}^{-1}$, which demonstrated the variety change of the peak. At $2967 \mathrm{~cm}^{-1}$ the band represented the peak of $\mathrm{CH}$ stretching bond from alkane $\mathrm{RCH}_{2} \mathrm{CH}_{3}$ group. It was related to the stretching of $\mathrm{CH}_{2}$ and $\mathrm{CH}_{3}$ bands at 1455 $\mathrm{cm}^{-1}$ with rocking of $\mathrm{C}-\mathrm{H}$ at $1361 \mathrm{~cm}^{-1}$ band. Lastly, the 
TABLE 4. Component composition in DGEBA/MMT systems

\begin{tabular}{llcc}
\hline Type & Component & Mass $(\%)$ & Atomic $(\%)$ \\
\hline \multirow{2}{*}{ DGEBA/PEA } & Carbon & 66.40 & 72.47 \\
& Oxygen & 33.60 & 27.53 \\
DGEBA/30B/PEA & Carbon & 78.98 & 84.72 \\
& Oxygen & 17.76 & 14.23 \\
& Silicon & 2.54 & 1.16 \\
& Aluminium & 0.72 & 0.34 \\
DGEBA/Na $/$ PEA & Carbon & 32.02 & 41.35 \\
& Oxygen & 50.10 & 48.57 \\
& Silicon & 12.16 & 6.72 \\
& Aluminium & 4.97 & 2.86 \\
& Sodium & 0.75 & 0.51 \\
& Carbon & 41.89 & 52.09 \\
& Oxygen & 44.64 & 41.67 \\
& Silicon & 8.08 & 4.30 \\
DGEBA/Sabah/PEA & Aluminium & 2.19 & 1.21 \\
& Calcium & 0.11 & 0.04 \\
& Ferum & 1.18 & 0.31 \\
& Zinc & 0.44 & 0.10 \\
& Bromine & 1.46 & 0.27 \\
\hline
\end{tabular}

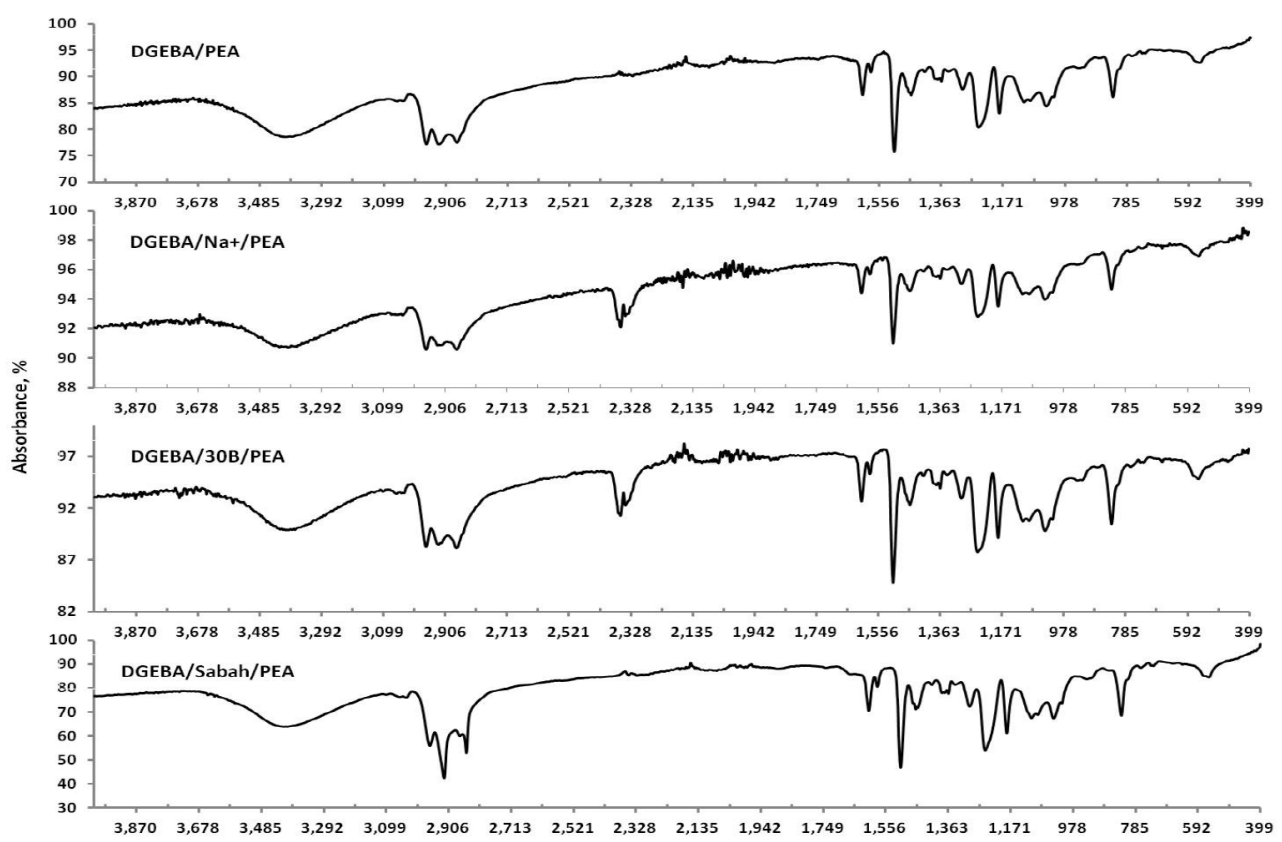

FIGURE 7. FTIR spectra for DGEBA/MMT systems

analysis showed that there was a $\mathrm{C}$ - $\mathrm{Br}$ bond stretching related to alkyl halide $\mathrm{CH}_{2} \mathrm{X}(\mathrm{C}-\mathrm{H} \mathrm{Wag})$ at $1246 \mathrm{~cm}^{-1}$ band as presented in Figure 7.

\section{CONCLUSION}

From the research, in can be concluded that the incorporation of nanofiller into the polymer matrix changes the thermal stability of the system. The introduction of thermally stable materials, which are aluminium and silicon, into the system can enhance the exposure of material to high temperature. The use of different types of montmorillonite can also change the thermal stability through several factors, which are polymer chain length and the dispersion of the structure, which are related to the sample preparation method. This experiment shows that sample DGEBA/Na ${ }^{+} /$ PEA requires higher energy to break the polymer bond to decompose. Although the initial decompose temperature of DGEBA/ $\mathrm{Na}^{+} /$PEA occurred earlier than DGEBA/30B/PEA, the breaking of the polymer bond took longer time than other samples. It can be concluded that Cloisite $\mathrm{Na}^{+}$filler produces stable system than others. Meanwhile, the system 
containing Sabah bentonite filler gives the lowest thermal stability due to the presence of impurities in its structure. However, it may have other advantages that need to be discovered in further studies, such as mechanical properties and water absorption.

\section{ACKNOWLEDGMENTS}

The author (Muhammad Noor Dzuhri bin Shohor) would like to acknowledge his parents for their blessing during the study and lab assistant En. Wan Mohd Nazir bin Wan Taha, as well as the public service department for the financial support. Also, the authors wish to acknowledge Universiti Kebangsaan Malaysia for GGPM-2013-24 grant to conduct the research.

\section{REFERENCES}

Arridge, R.G.C. \& Speake, J.H. 1972. Mechanical relaxation studies of the cure of epoxy resins: 1. Measurement of cure. Polymer 13(9): 443-449.

Becker, O. \& Simon, G.P. 2005. Epoxy layered silicate nanocomposite. Advanced Polymer Science 179: 29-82.

Cárdenas, M.Á., García-López, D., García-Vilchez, A., Fernández, J.F., Merino, J.C. \& Pastor, J.M. 2009. Synergy between organo-bentonite and nanofillers for polymer based fire retardant applications. Applied Clay Science 45(3): 139-146.

Carrasco, F. \& Pagès, P. 2008. Thermal degradation and stability of epoxy nanocomposites: Influence of montmorillonite content and cure temperature. Polymer Degradation and Stability 93(5): 1000-1007.

Chiang, C.L., Chang, R.C.\& Chiu, Y.C. 2006. Thermal stability and degradation kinetic of novel organic/inorganic epoxy hybrid containing nitrogen/silicon/phosphorus by sol-gel method. Thermochimica Acta 453: 97-104.

Dat, Mohdkhairul Azfar Moh. 2013. Kesan jisim dan olahan permukaan nanosilika ke atas kinetik pematangan epoksi berpengisi nanozarah silika. Bachelor Degree in Chemical Engineering Research, Chemical Engineering, Universiti Kebangsaan Malaysia (Unpublished).

Erdemoğlu, M., Erdemoğlu, S., Sayılkan, F., Akarsu, M., Şener, Ş., \& Sayılkan, H. 2004. Organo-functional modified pyrophyllite: Preparation, characterisation and $\mathrm{Pb}(\mathrm{II})$ ion adsorption property. Applied Clay Science 27(1-2): 41-52.

Grillet, A.C., Galy, J., Gerald, J.F. \& Pascault, J.P. 1991. Mechanical and viscoelastic properties of epoxy networks cured with aromatic diamines. Polymer 32(10): 1885-1891.

Gu, A. \& Liang, G. 2002. Thermal degradation behaviour and kinetic analysis of epoxy/montmorillonite nanocomposites. Polymer Degradation and Stability 80(2): 383-391.
Hussin, F., Aroua, M.K. Daud, W.M.A.W. 2011. Textural characteristics, surface chemistry and activation of bleaching earth: A review. Chemical Engineering Journal 170(1): 90-106.

Irawan, S.\& Samsuri, A. 2007. Drilling mud material cost saving through utilization of treated Malaysian local bentonite. Mineral Symposium 2007.

Isik-Gulsac, I., Yilmazer, U. \& Bayram, G. 2003. Impact modified epoxy/montmorillonite nanocomposites: Synthesis and characterization. Polymer 44(20): 6371-6377.

Ruiz-Hitzky, E., Aranda, P., Álvarez, A., Santarén, J. \& EstebanCubillo, A. 2011. Chapter 17 - Advanced materials and new applications of sepiolite and palygorskite. In Developments in Clay Science, edited by Galàn Emilio \& Singer Arieh, Elsevier. pp. 393-452.

Sayılkan, H., Erdemoğlu, S., Şener, Ş., Sayılkan, F., Akarsu, M. \& Erdemoğlu, M. 2004. Surface modification of pyrophyllite with amino silane coupling agent for the removal of 4-nitrophenol from aqueous solutions. Journal of Colloid and Interface Science 275(2): 530-538.

Tcherbi-Narteh, A., Hosur, M., Triggs, E. \& Jeelani, S. 2013. Thermal stability and degradation of diglycidyl ether of bisphenol A epoxy modified with different nanoclays exposed to UV radiation. Polymer Degradation and Stability 98(3): 759-770.

Yuhana, N.Y., Ahmad, S., Kamal, M.R., Jana, S.C. \& Shamsul Bahri, A.R. 2012. Thermal stability and morphology of roomtemperature cured PMMA grafted natural rubber toughened epoxy/layered silicate nanocomposite. Polymer Processing Society 28th Annual Meeting, Pattaya (Thailand).

Zhou, Y., Pervin, F., Rangari, V.K. \& Jeelani, S. 2007. Influence of montmorillonite clay on the thermal and mechanical properties of conventional carbon fiber reinforced composites. Journal of Materials Processing Technology 191(1-3): 347-351.

Department of Chemical and Process Engineering Faculty of Engineering and Built Environment Universiti Kebangsaan Malaysia 43000 Bangi, Selangor Darul Ehsan Malaysia

*Corresponding author; email: yuliana@eng.ukm.my

Received: 5 May 2014

Accepted: 3 September 2014 